\title{
The immune status of patients with HIV infection, combined with chronic viral hepatitis $C$
}

\begin{abstract}
Characteristic for HIV changes are significant decrease in the number of T-helper / inducer $(\mathrm{CD} 3+\mathrm{CD} 4+)$, natural killer cells $(\mathrm{CD}-\mathrm{CD} 16+\mathrm{CD} 56+)$ and the coefficient ratio of $\mathrm{CD} 3+\mathrm{CD} 4+/ \mathrm{CD} 3+\mathrm{CD} 8+$. An opposite pattern of change in the direction of increasing the content recorded in the cytotoxic T-lymphocytes $(\mathrm{CD} 3+\mathrm{CD} 8+)$, killer T lymphocytes $(\mathrm{CD} 3+\mathrm{CD} 16+\mathrm{CD} 56+)$ and lymphocytes expressing activation antigens (CD3 + HLA-DR+; CD71+ CD8+ CD38+), including the CD95+ cells, inducing apoptosis. In patients with mixed infection is observed more pronounced degree of expression FH0-alpha and IFNYon lymphocytes, induced by HIV. Of particular importance is the decrease in serum cytotoxin Th-cells-IFN-YHIV infection was most pronounced in patients with mixed pathology. INSTALLATIONS pronounced increase of serum cytokine TNF- $\alpha$ in patients with concomitant pathology than with monoinfection. Similar orientation changes of Th2 cytokine-cells - interleukin-4 is observed in HIV infections, especially when it is combined with current HCV. Revealed significant B lymphopenia and polyclonal activation of CD19+ cells, which was characterized by increased content of $\operatorname{IgA}, \operatorname{IgM}, \operatorname{IgG}$, IgE, more pronounced when the mixed pathology. Prognostic criteria more rapid progression of HIV infection in patients with $\mathrm{HCV}$ are increasing the number of cytotoxic $\mathrm{T}$ lymphocytes expressing CD38 (CD8+ CD38+), receptor Fas -apoptoza CD95+, elevation of serum cytokines (TNF- $\alpha$, IL-4) and reduced IFN levels -Y.
\end{abstract}

Keywords: HIV infection, chronic viral hepatitis C, HIV-associated infections, immune status, progression forecast
Volume 6 Issue 5 - 2018

VV Mefodev, ${ }^{1,2}$ VA Savin,' PV Istomin'

'FGBOUVO Tyumen State Medical University Ministry of Health of Russia, Tyumen

${ }^{2}$ Federal Budget Institution of Science Tyumen Research Institute of Regional Infectious Pathology, Tyumen

Correspondence: VV Mefodev, IFGBOUVO Tyumen State Medical University Ministry of Health of Russia,Tyumen, Tel +7 90449575 41, Email vmefadyev@mail.ru

Received: June II, 2018 | Published: October 29, 2018

\section{Introduction}

At the turn of the twentieth and HH1 centuries the spread of HIV infection in Russia was due, primarily, with a high frequency of registration of cases of diagnosed HIV infection among people who use intravenous administration of psychoactive substances (PAS). ${ }^{1,2}$ In this population simultaneously with the human immunodeficiency virus and hepatitis viruses spread parenteral transmission mechanism. ${ }^{3,4}$ In Russian territory antibodies to hepatitis $\mathrm{C}$ virus was determined at $75-95 \%$ of individuals infected with HIV when administered intravenously surfactant. ${ }^{5}$ The simultaneous development of infectious disease is characterized by two distinct polymorphic clinical manifestations of each of them, which creates significant difficulties in early diagnosis and etiological deciphering mixed infections. ${ }^{6} \mathrm{We}$ are still poorly understood pathogenetic mechanisms, causing a flow of mixed infections especially not effective methods of treatment and prevention of infectious diseases. ${ }^{3,7}$ The purpose of this study was to evaluate some parameters of the immune status of patients infected with human immunodeficiency, combined with chronic hepatitis $\mathrm{C}$ virus $(\mathrm{HCV})$.

\section{Materials and methods}

The study included 51 patients, among them were 32 men and 19 women aged 18-50 years. The main group consisted of 31 patients with $\mathrm{HIV}$, chronic hepatitis $\mathrm{C}$ combined with (co-infection). Control were 20 HIV-infected patients without comorbidity (monoinfection) and 30 healthy individuals did not differ by sex and age from the main group. The diagnosis in all patients confirmed seropozitivnmi research on HIV ELISA and immunoblotting. HBV verification conducted detection of anti-HCV ELISA in screening and confirmatory test systems and the results of clinical, epidemiological and paraclinical examinations. Serological study included determination of the specific antibody classes $\mathrm{G}$ and $\operatorname{IgM}$ peripheral blood by radial immunodiffusion kits using monospecific antisera to different Ig classes. Anti-HIV antibodies were measured by ELISA test systems "HIV-1, HIV-2IFA- Avicenna (firm" Avicenna ", Russia) and KombiBest anti-HIV $1+2$ (firm" Vector Best ", Russia) Serological. blood tests for HCV markers was performed using HBV ETC test systems -AB-COREK-2, ETI CORE-IgM-2 ETI-AUK-3 production "Dia Sorin" (Italy). When monitoring HIV activity was determined by anti-HIV antibodies and quantitative study of HIV RNA (number of copies / ml) by PCR. $\mathrm{HCV}$ genotyping was carried out in accordance with the orders of the Ministry of Health of Russia. Study of the immune status of patients with HIV, HCV+ HIV included determination of total leukocytes, lymphocytes and their subpopulations. Immunophenotyping populations and subpopulations of peripheral blood lymphocytes was performed by flow laser cytometry (FAC Scan Becton Dickinson). It determines the number of CD3+ (T-lymphocytes), CD4+ (T-helper), CD8+ (T-tsitotoksichekie suppressors), CD 20+ (B- lymphocytes), CD56+ (NK - cells), CD54+ (lymphocytes expressing the adhesion molecule I CAM-1) HLA-DR+ (activated cells expressing class II molecules GCS), CD25+ (receptor for IL-2 on ativirovannyh lymphocytes), CD95+ (Fas, a - 1 - induction of apoptosis). Calculated helper-suppressor ratio (D4+/CD28+).

\section{Results and discussion}

When comparing the status of $\mathrm{HIV}+$ patients with $\mathrm{HCV}$ control (Table 1) showed a significant reduction in the number of T-lymphocytes $(\mathrm{CD} 3+)$ compared with the control (respectively $56.2 \pm 3.8 \%$ and $68,0 \pm 4,2 \%$ ); T-helpers (CD4+) $-30,0 \pm 3,3 \%$ and 
$0.4 \pm 0.08 \%, 109 / \mathrm{L})$ in the control (CD4 - 43,0 $2,8 \% ; 0,6 \pm 0,05 \%$, $109 / 1$; helper-suppressor ratio (CD4+/CD8+) 1,14 $\pm 0,08 \%$; in control- $1,7 \pm 0,2 \%$. The results immunophenotyping of lymphocytes $\mathrm{CD} 3+\mathrm{CD} 4+$, include T-helper subset cells, patients co-infected show a pronounced decrease in their number $(\mathrm{p}<0.01)$, respectively 2.2 and 2.1 times less than the reference values of these parameters in healthy individuals $(44,09 \pm 1,12 \% ; 0,99 \pm 0,07 \times 109 / 1)$. It should be noted that patients monoinfection reduction of $\mathrm{CD} 3+\mathrm{CD} 4+$ lymphocytes $(35,16 \pm 2.27 \% ; \mathrm{p}<0.01 ; 0.70 \pm 0.06 \times 109 / \mathrm{L} ; \mathrm{p}<0.001)$ was observed in less $(1.3$ times $)$ degree. It installs a significant $(p<0.01)$ decrease in the number of immune cells with the phenotype of CD3+CD4+ in patients with HIV infection associated with chronic HCV than patients with monoinfection including cytotoxic $\mathrm{T}$ lymphocytes in patients with concomitant pathology $(58,87 \pm 1.99 \% ; 1.37 \pm 0.15 \times 10$ 9/1) allowed to establish their number increased $(\mathrm{p}<0.01)$ respectively and 2.5 and 2.7 times the standard values $(44,09 \pm 1.12 \% ; 0.99 \pm 0.07 \times 109 / \mathrm{L})$. Similar data increasing the amount of CD3+ CD4+ lymphocytes, and marked monoinfection patients $(47.0 \pm 1.87 \% ; 0.98 \pm 0.10 \times 10$ 9/1), but these changes were less pronounced $(\mathrm{p}<0.01)$ and greater than 2 times the norm indicators. It should be pointed out that a significant

Table I Indicators of immune status of patients with HIV infection concomitant with chronic hepatitis $C$

Note: $*$ - reliability of differences from the control group performance at $*$ - $p<0,05$; *** $-p<0,01$; P 2-3 - significance of differences between treatment groups; abs. - $1.0 \times 109 / 1$

\begin{tabular}{|c|c|c|c|c|}
\hline \multirow[t]{3}{*}{ Investigated Indicators } & Control Group & $\begin{array}{l}\text { HIV infection, combined with chronic } \\
\text { hepatitis C (co-infection) }\end{array}$ & $\begin{array}{l}\text { HIV infection (Monoinfek- } \\
\text { tion) }\end{array}$ & P 2-3 \\
\hline & I - group & II - Group & III - Group & \\
\hline & $\mathbf{N}=\mathbf{3 0}$ & $\mathbf{N}=3 \mathbf{I}$ & $\mathbf{N}=\mathbf{2 0}$ & \\
\hline $\mathrm{CD} 3+, \%$ & $77.17 \pm 1.45$ & $80.22 \pm 2.65$ & $82.19 \pm 1.77$ & $\mathrm{p} 0,05$ \\
\hline CD3 +, abs. & $1.66 \pm 0.09$ & $\mathrm{I}, 890,2 \pm \mathrm{I}$ & $1,640, \pm 13$ & $\mathrm{P} 0,05$ \\
\hline $\mathrm{CD} 3+\mathrm{CD} 4+, \%$ & $44.09 \pm 1.12$ & $19,79 \pm 146 * * *$ & $35,16 \pm 2,27 * * *$ & $\mathrm{p}<0,00 \mathrm{I}$ \\
\hline $\mathrm{CD} 3+\mathrm{CD} 4+$, abs. & $0.99 \pm 0.07$ & $0,480,0 \pm 6 * * *$ & $0,70, \pm 06 * *$ & $\mathrm{P}<0,0$ I \\
\hline $\mathrm{CD} 3+\mathrm{CD} 8+, \%$ & $23.76 \pm 0.75$ & $58,87 \pm 1,99 * * *$ & $47,2 \pm 1,87 * * *$ & $p>0,05$ \\
\hline $\mathrm{CD} 3+\mathrm{CD} 8+$, abs. & $0.50 \pm 0.03$ & $1.37 \pm 0.15 * * *$ & $0.98 \pm 0.1 * * *$ & $\mathrm{p}<0,05$ \\
\hline $\mathrm{CD} 4+/ \mathrm{CD} 8+$ & $1.98 \pm 0.08$ & $0.33 \pm 0.02 * * *$ & $0.77 \pm 0.07 * * *$ & $p>0,05$ \\
\hline $\mathrm{CD} 3+\mathrm{CD} 16+$ & $2.33 \pm 0.29$ & $8.67 \pm 1.94 * * *$ & $5.83 \pm 1.55$ & $p>0,05$ \\
\hline \multicolumn{5}{|l|}{ CD56 +,\% } \\
\hline $\begin{array}{l}\text { CD3 + CDI6 + CD56 +, } \\
\text { abs. }\end{array}$ & $0.05 \pm 0.01$ & $0.25 \pm 0.07$ ** & $0.1 \pm 0.03$ & $p>0,05$ \\
\hline $\mathrm{CD} 3+\mathrm{CD} 16+$ & $12,54 \pm 126$ & $7.1 \pm 0.89 * * *$ & $4,6 \pm 055 * * *$ & $p>0,05$ \\
\hline \multicolumn{5}{|l|}{ CD56 +,\% } \\
\hline $\begin{array}{l}\mathrm{CD} 3+\mathrm{CD} 16+\mathrm{CD} 56+\text {, } \\
\text { abs. }\end{array}$ & $0.3 \pm 0.03$ & $0.17 \pm 0.03 * * *$ & $0.1 \pm 0.01 * * *$ & $p>0,05$ \\
\hline CD3 + HLA-DR +,\% & $2.55 \pm 0.77$ & $14,19 \pm 1,79 * * *$ & $15,45 \pm 2,59 * * *$ & $p>0,05$ \\
\hline CD3 + HLA - DR +, abs. & $0.06 \pm 0.003$ & $0.34 \pm 0.05 * * *$ & $0.33 \pm 0.08 * * *$ & $p>0,05$ \\
\hline CD7I,$+ \%$ & $1.59 \pm 0.13$ & $2,62 \pm 0,33 * *$ & $2,95 \pm 0,61 *$ & $p>0,05$ \\
\hline CD7I +, abs. & $0.04 \pm 0.003$ & $0.05 \pm 0.01$ & $0.06 \pm 0.01$ & $p>0,05$ \\
\hline CD38,$+ \%$ & $83.68 \pm 2.32$ & $74.04 \pm 4.89$ & $78.82 \pm 9.69$ & $p>0,05$ \\
\hline CD38 +, abs. & $2.09 \pm 0.1$ & $1.39 \pm 0.14 * * *$ & $1,54 \pm 0,21 * *$ & $p>0,05$ \\
\hline $\mathrm{CD} 8+/+38 \%$ & $4.08 \pm 0.6 \mathrm{I}$ & $24,57 \pm 3,64 * * *$ & $23,34 \pm 2,76 * * *$ & $p>0,05$ \\
\hline $\mathrm{CD} 8+/ 38+$, abs. & $0.07 \pm 0.0 \mathrm{I}$ & $0.69 \pm 0.14 * * *$ & $0.42 \pm 0.06 * * *$ & $p>0,05$ \\
\hline CD95 +,\% & $22.58 \pm 0.99$ & $32.0 \pm 3.34$ & $36,86 \pm 5,27 * * *$ & $p>0,05$ \\
\hline CD95 +, abs. & $0.56 \pm 0.03$ & $0.7 I \pm 0.07$ & $0.67 \pm 0.09$ & $p>0,05$ \\
\hline TNF - $\alpha$ (spontaneous)\% & $0,0 \pm \_0,01$ & $2,14 \pm 0,67 * *$ & $1.16 \pm 0.87$ & $p>0,05$ \\
\hline
\end{tabular}

increase in cytotoxic $\mathrm{T}$ lymphocytes CD3+ CD4+ was observed when co-infection, than when monoinfection, but these changes were not statistically significant character $(\mathrm{p}<0.05)$. 10x10 9/L), but these changes were less pronounced $(\mathrm{p}<0.01)$ and 2-fold higher than the norm metrics. It should be pointed out that a significant increase in cytotoxic $\mathrm{T}$ lymphocytes CD3+ CD4+ was observed when coinfection, than when monoinfection, but these changes were not statistically significant character $(\mathrm{p}<0.05) .10 \times 109 / \mathrm{L})$, but these changes were less pronounced $(\mathrm{p}<0.01)$ and 2 -fold higher than the norm metrics. It should be pointed out that a significant increase in cytotoxic T lymphocytes CD3+CD4+ was observed when coinfection, than when monoinfection, but these changes were not statistically significant character $(p<0.05)$. Because of alternate changes the content of lymphocytes with a phenotype CD3+ CD4+ and $\mathrm{CD} 3+\mathrm{CD} 8+$ ratio ratio of these cells in patients of the main group surveyed $(0,33 \pm 0,02)$ decreased significantly $(p<0,01)$ than normal $(1,98 \pm 0,08)$. When monoinfection ratio coefficient data cells $(0,77 \pm 0,07)$ decreased $(p<0.01)$ less and recorded in 2.6 times control values. 


\begin{tabular}{|c|c|c|c|c|}
\hline IFNY(spontaneous),\% & $0.04 \pm 0.02$ & $0,66 \pm 0,31 *$ & $0.2 I \pm 0.1$ & $p>0,05$ \\
\hline TNF- $\alpha, p g / m l$ & $2.06 \pm 0.06$ & $8.02 \pm 0.54 * * *$ & $3,52 \pm 0,0,12 * *$ & $\mathrm{P}<0,0$ ㅇ \\
\hline IL-4 pg/ml & $9.8 \pm 0.34$ & $35,65 \pm 1,96 * * *$ & $30,72 \pm 2,0$ I $* * *$ & $p>0,05$ \\
\hline IFN -Y pg/ml & $|7.3 \pm 0.5|$ & $7.86 \pm 0.47 * * *$ & $12,17 \pm 0,89 * * *$ & $\mathrm{P}<0,0$ ㅇ \\
\hline CD3+CD $19+, \%$ & $8.81 \pm 0.58$ & $4,35 \pm 0,43 * * *$ & $4,26 \pm 0,62 * * *$ & $p>0,05$ \\
\hline CD3+CD19+, abs. & $0.2 \pm 0.07$ & $0.1 \pm 0.0 I$ & $0.08 \pm 0.01$ & $p>0,05$ \\
\hline $\lg A, g / \mid$ & $1.96 \pm 0.11$ & $4,99 \pm 0,33 * * *$ & $1,9 \pm 0,18$ & $\mathrm{p}<0,0$ I \\
\hline $\lg M, g / l$ & $1.84 \pm 0.12$ & $4,56 \pm 0,31 * * *$ & $2.22 \pm 0.16$ & $\mathrm{P}<0,0$ I \\
\hline $\lg \mathrm{G}, \mathrm{g} / \mathrm{l}$ & $13.79 \pm 0.86$ & $26,18 \pm 1,62 * * *$ & $16.55 \pm 1.23$ & $\mathrm{P}<0,0$ I \\
\hline $\lg \mathrm{E}, \mathrm{IU} / \mathrm{ml}$ & $33.8 I \pm 1.44$ & $|43,3 \pm| 3,4 \mid * * *$ & $84,16 \pm 3,96 * * *$ & $p<0,0$ l \\
\hline
\end{tabular}

\section{Results}

This result of studying a subpopulation of T-killer lymphocytes CD3+CD16++ SD56 in patients co-infected $(8,67 \pm 1,94 \% ; \mathrm{p}<0.01$; $0.25 \pm 0.07 \times 109 / \mathrm{L} ; \mathrm{p}>0,01$ ) indicates a significant increase of greater than respectively 3.7 times and 5 times with similar standards indicators $(2,33 \pm 0,29 \% ; 0,05 \pm 0,01 \times 109 / 1)$. The increase of the T killer lymphocytes of patients monoinfection $(5,83 \pm 1.55 \% ; 0.01 \pm 0.03 \times 10$ $9 / \mathrm{L}$ ) noted in a lesser degree ( $>0.05$ ) compared with those of both primary and control groups. Comparative analysis of lymphocytes with a phenotype of CD3+C16+CD56+ $(7,10 \pm 0,89 \% ; 0,17 \pm 0,03 \times 10$ $9 / \mathrm{L} ; \mathrm{p}<0,01)$ in most patients with mixed-pathology showed that the amount of natural killer cells was reduced 1.8 and 1.7 fold compared to controls $(12,54 \pm 1,26 \% ; 0,30+ \pm 0,08 \times 109 / 1)$. When monoinfection examined patients observed a more pronounced ( 2.7 and 3 times) reduction of $\mathrm{CD} 3+\mathrm{CD} 16+\mathrm{CD}+56+$ lymphocytes $(4,60 \pm 0.55 \%$; $\mathrm{p}<0.01 ; 0.10 \pm 0.01 \times 109 / 1)$ compared with the corresponding standard values. Determination method of immunophenotyping number of activated T-lymphocytes expressing HLA-DR - antigen (CD3+ HLA- DR+) allowed to establish a significant increase $(\mathrm{p}<0.01)$ in patients with their contents mixed infection $(17,19 \pm 1,79 \%$; 0 , $34 \pm 0,05 \times 109 / 1)$ which was significantly (5.6-fold) greater than the standard values $92,55 \pm 0,17 \% ; 0.06 \pm 0.003 \times 109 / 1)$. Similar data were obtained when studying the content of activated T-lymphocytes in patients monoinfection $(15,45 \pm 2,59 \% ; \mathrm{p}<0.01)$, respectively, 6.1 and 5 times more than in healthy persons. Investigation of immune cells expressing a marker for aktivivatsionny transferrin receptor $(\mathrm{CD} 71+)$, in the examinees with mixed infection $(2,62 \pm 0,33 \%)$ set $(p<0,01)$ increase in their contents, but the absolute number of CD71+ $(0,05 \pm 0,01 \times 109 / 1)$ tended to increase $(p<0,05)$. The content of $\mathrm{CD} 71+$ positive cells in patients monoinfekiey $(2.95 \pm 0.61 \%$; $\mathrm{p}<0.05 ; 0.06 \pm 0.01 \times 109 / \mathrm{L} ; \mathrm{p}<0,05)$ had the same pattern of change as compared with normative indicators $(1.59 \% \pm 0.13 ; 0.003 \pm 0.04 \times 10$ 9/1). Comparative study content CD8+ subpopulation of lymphocytes expressing CD38 in patients with mixed infection $(24.57 \pm 3.64 \%$; $0.69 \pm 0.14 \times 109 / \mathrm{L})$ and monoinfection $(23,34 \pm 2,76 \% ; 0.42 \pm 0.06 \times 10$ 9/1) revealed their increase, which exceeded the reference value $(4.08 \% \pm 0.61 ; 0.001 \pm 0.07 \times 109 / 1)$ was mixed with 6-pathology and 9.9 times and monoinfection-5.7 and 6 times. Determination of total content of lymphocytes expressing the activation marker $\mathrm{CD} 38+$, allowed to establish a moderate reduction of their content in patients of the main group $(74.04 \pm 4.89 ; \mathrm{p}<0.05 ; 1.329 \pm 0.14 \times 109 / \mathrm{L}$; $\mathrm{p}<0,01)$. Changes in $\mathrm{CD} 38+$ lymphocytes monoinfection positive $(78.82 \pm 9.69 \% ; \mathrm{p}<0.05 ; 1.54 \pm 0.21 \times 109 / \mathrm{L} ; \mathrm{p}<0.01)$ was observed to a lesser extent as compared with the control indices groups $(83,68 \pm 2,32 \% ; 2,09 \pm 0,10 \times 109 / 1)$. The received data analysis of the number of lymphocytes expressing CD95+ cells and induce apoptosis

in patients with mixed infection $(32,0 \pm 3,34 \% ; 0,71 \pm 0,07 \times 10$ 9/1) indicate a tendency of increase ( $>00,05)$, their number in comparison with the norm $(22.58 \pm 0.99 \% ; 0.56 \pm 0.03 \times 109 / 1)$. When the relative content monoinfection CD95+ positive lymphocytes $(36,86 \pm 5,27 \times 10$ $9 / \mathrm{L} ; \mathrm{p}<0,01)$ significantly increased, while the absolute number of these cells $(0,67 \pm 0,09 \times 109 / 1)$ had only a tendency to increase $(p>0,05)$. Investigation of the number of lymphocytes expressing receptors of tumor necrosis factor (TNF- $\alpha$ ) HIV infection, combine with $\operatorname{HCV}(2,14 \pm 0,67 \%)$, revealed a significant $(p<0,01)$ increase in their content compared with the norm.

It should also be noted that when monoinfection patients examined the number of lymphocytes expressing TNF - $\alpha$, also increased $(1,16 \pm 0,87)$, but did not differ significantly $(p>0,05)$ from control values. Determination of mononuclear cells expressing IFN receptorsYInduced Th1 - lymphocytes in patients co-infected $(0,66 \pm 0,31 \%)$ established significant $(p>0,05)$ increase in their number with values standards $(0,04 \pm 0,02)$. It showed an increase in the number of cells expressing IFN receptorsYIn patients monoinfection $(0,21 \pm 0,1 \%)$, but the increase of their content was not statistically significant $(p>0,05)$. Serum TNF- $\alpha$ in the examined groups was significantly $(\mathrm{p}<0,01)$ above when mixed pathology $(8,02 \pm 0,54 \mathrm{pg} / \mathrm{ml})$ than monoinfection $(3,52 \pm 0,12 \mathrm{pg} / \mathrm{ml} ; \mathrm{p}<0.01)$, respectively, in excess of 3.9 and 2.3 times the norm indicators $(2,06 \pm 0,06 \mathrm{pg} / \mathrm{ml})$. The increase of serum TNF- $\alpha$, macrophageinduced monocytic cell link, when mixed infection was noted in significantly greater concentration $(p<0,01)$ in comparison with its level at monoinfection. The study of serum IFNYProduced Th1lymphocytes in patients with concomitant pathology revealed that when the amount of mixed infection of this cytokine $(7,86 \pm 0,47 \mathrm{pg}$ $/ \mathrm{ml})$ significantly $(2.2$-fold $)$ decreased $(\mathrm{p}<0,01)$ compared with the norm $(17,3 \pm 0,51 \mathrm{pg} / \mathrm{ml})$. Decrease in serum IFN-cytotoxinY patients monoinfection $(12,17 \pm 0,89 \mathrm{pg} / \mathrm{ml} ; \mathrm{p}<0,01)$ noted in a lesser degree $(1.5$-fold $)$ and was significantly higher $(\mathrm{p}<0,01)$, than in patients with mixed infection. Analysis results of the study the serum IL-4-induced Th2 - lymphocytes with mixed pathology showed that the level of this cytokine $(35.65 \pm 1,96 \mathrm{pg} / \mathrm{ml} ; \mathrm{p}<, 001)$ of the patients in 3.6 times the norm metrics $(9,8 \pm 0,3 \mathrm{pg} / \mathrm{ml})$. Increased IL-4 concentration in patients with monoinfection $(30,72 \pm 2,01 \mathrm{pg} / \mathrm{ml})$ was observed to a lesser extent and 1.2 times the level of the control group. Study number of B-lymphocytes (CD19+) in patients with $\mathrm{HCV}+\mathrm{HIV}$, has allowed to establish a significant $(\mathrm{p}<0,01)$ decrease in their relative content $(4,35 \pm 0,435)$, and their absolute number $(0,10 \pm 0,01 \times 109 / 1)$, reduced to a lesser extent $(\mathrm{p}<0,05)$ than normal $(8,81 \pm 0,58 \% ; 0,2 \pm 0,07 \mathrm{x}$ 109/1). Patients monoinfection observed similar dynamics content changes CD19+ lymphocytes $(4.26 \pm 0.62 \%$; $p<0.001 ; 0.08 \pm 0.01 \times 10$ $9 / \mathrm{L} ; \mathrm{p}>0,05)$. Determining the concentration of Ig classes A, M, G 
and $\mathrm{E}$ are allowed to establish polyclonal activation of B-lymphocytes in patients with HIV infection, as evidenced by their high level. A content Ig $(4,99 \pm 0,33 \mathrm{~g} / 1), \operatorname{Ig} \mathrm{M}(4,56 \pm 0,31 \mathrm{~g} / 1), \operatorname{Ig~G}(26,18 \pm 1,62 \mathrm{~g} / \mathrm{l})$ and Ig E $(1434 \pm 13,41 \mathrm{ME} / 1)$ in patients with mixed pathologies, significantly exceeded $(2.5 ; 2.5 ; 1.9$ and 4.2 times $)$, respectively, the levels of the control group of healthy individuals $(\operatorname{IgA}-1.96 \pm 0.11 \mathrm{~g} / 1$;

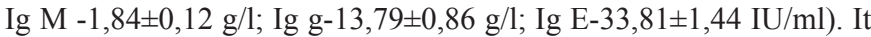
should be noted that patients monoinfection increasing concentrations of the specific Ig was observed to a lesser extent: $\operatorname{IgA}-1,9 \pm 0,18 \mathrm{~g} / 1$; $(\mathrm{P}>0,05) ; \operatorname{IgM}-2,22 \pm 0,16 \mathrm{~g} / 1 ; \mathrm{p}>0,05 ; \operatorname{Ig} \mathrm{G}-16,55 \pm 1,23 \mathrm{~g} / 1 ;(\mathrm{P}>0,05)$ Ig E-84,16 $\pm 3,96 \mathrm{IU} / \mathrm{ml}(\mathrm{p}<0,01)$. Comparative analysis of Ig studied showed that patients with mixed infection IgA concentration, Ig M, The obtained results of the study of some indicators immunogram patients combined course of HIV infection and chronic hepatitis $\mathrm{C}$ indicates poor course of co-infection, each of these two infectious diseases acquires a progressive progressive nature, it aggravates the course of disease and the need to find effective treatments for patients with co-infection (Table 1).

\section{Acknowledgements}

None.

\section{Conflict of interest}

There is no conflict of interest among the authors.

\section{References}

1. Belozerov. ES HIV/ES. Belozerov, Yu I Bulashev Elista, editors. AMS «Dzhangar; 2006:324 p

2. Pokrovsky VI. Topical issues of treatment and prevention in terms of the evolution of infectious diseases. Infectious Diseases. 2003;1(1):S6-S8.

3. Granitov VM. AIDS-related infections and infestations/VM Granites. Barnaul: CAP, IPP «Altai»; 2011:288 p.

4. Zigalenko DP, Volzhanin VM, VN Bolehan, et al. Soputstvuyuschie disease in HIV-infected individuals younger. Materials of VI Russian Congress of infectious disease specialists. 2003:149 p.

5. Ioannidi EA. Comparative immunological characteristics of chronic hepatitis $C$ and $B+C$ in HIV-infected drug users. Proceedings of the Russian Congress of infectious disease specialists. 2003:157 p.

6. Prichiny mixed processes in HIV/T Yu Kuzmin, EP Tihonova, GG Strokina//Materials of X VNPOEMiP Congress Results and prospects for epidemiological welfare of the population of the Russian Federation. 2012 April 12-13; Moscow. 2012:416-417.

7. VG Kanestri, AV Kravchenko, OA Tishkevich. Hronichesky hepatitis C in HIV-infected. Epidemiology and infectious diseases. 2001;1:S56-S57. 